\title{
Investigation of the reactivity properties of a thiourea derivative with anticancer activity by DFT, MD simulations
}

Sheena Mary ( $\square$ marysheena2018@rediffmail.com )

Researcher, Thushara, Neethinagar-64, Kollam https://orcid.org/0000-0002-9082-3670

\section{Y. Shyma Mary}

Researcher, Thushara, Neethinagar-64, Kollam

Anna Bielenica

Medical University of Warsaw: Warszawski Uniwersytet Medyczny

Stevan Armaković

University of Novi Sad: Univerzitet u Novom Sadu

Sanja J. Armaković

University of Novi Sad: Univerzitet u Novom Sadu

Vivek Chandramohan

Siddaganga Institute of Technology

Manjunath Dammalli

Siddaganga Institute of Technology

\section{Research Article}

Keywords: DFT, thiourea, MD simulations, Docking, NLO

Posted Date: May 27th, 2021

DOl: https://doi.org/10.21203/rs.3.rs-178851/v1

License: (c) (i) This work is licensed under a Creative Commons Attribution 4.0 International License. Read Full License 
Investigation of the reactivity properties of a thiourea derivative with anticancer activity by DFT, MD simulations

\author{
Y.Sheena Mary ${ }^{a^{*}}$, Y.Shyma Mary ${ }^{\mathrm{a}}$, Anna Bielenica ${ }^{\mathrm{b}}$, Stevan Armakovićc ${ }^{\mathrm{c}}$, Sanja J. \\ Armakovićd $^{\mathrm{d}}$, Vivek Chandramohan ${ }^{\mathrm{e}}$, Manjunath Dammalli ${ }^{\mathrm{e}}$ \\ ${ }^{a}$ Researcher, Thushara, Neethinagar-64, Kollam, Kerala, India \\ ${ }^{\mathrm{b}}$ Chair and Department of Biochemistry, Medical University of Warsaw, 02-097 Warszawa, \\ Poland \\ 'University of Novi Sad, Faculty of Sciences, Department of Physics, \\ Trg D. Obradovića 4, 21000 Novi Sad, Serbia \\ ${ }^{d}$ University of Novi Sad, Faculty of Sciences, Department of Chemistry, Biochemistry and \\ Environmental Protection, Trg D. Obradovića 3, 21000 Novi Sad, Serbia \\ eDepartment of Biotechnology, Siddaganga Institute of Technology, Tumakuru, 572103, \\ Karnataka, India
}

*author for correspondence: marysheena2018@,rediffmail.com

\begin{abstract}
Spectroscopic analysis of 1-(2-fluorophenyl)-3-[3-(trifluoromethyl)phenyl]thiourea (FPTT) is reported. Experimental and theoretical analysis of FPTT, with Molecular Dynamics (MD) simulations, are reported for finding different parameters like: identification of suitable excipients, interactions with water, and sensitivity towards autoxidation. Molecular dynamics and docking show that FPTT can act as a potential inhibitor for new drug. Additionally, local reactivity, interactivity with water, and compatibility of FPTT molecule with frequently used excipients have been studied by combined application of density functional theory (DFT) and MD simulations. Analysis of local reactivity has been performed based on selected fundamental quantum-molecular descriptors, while interactivity with water was studied by calculations of radial distribution functions (RDFs). Compatibility with excipients has been assessed through calculations of solubility parameters, applying MD simulations.
\end{abstract}

Keywords: DFT; thiourea: MD simulations; Docking; NLO

\title{
1. Introduction
}

Thiourea derivatives have diverse biological activities, like antibacterial and anticancer as well as they have a high impact on the central nervous system of rodents [1-12]. Among thiourea's, molecules incorporating 3-(trifluoromethyl)phenyl moiety are known for their strong inhibitory effect on Gram-positive pathogens [1]. Their potency was noticeable towards both planktonic and biofilm-forming structures of staphylococcal species [13, 14]. Thiourea-derived connections exert also cytotoxicity against different cell lines tissues [15, 16], as well as the panel of viruses [17-22]. Additionally, thiourea compounds are extensively used for coordination complexes with metal ions [23-25] or cyclic derivatives such as tetrazoles [26] that could serve as medicinal agents. Thiourea structures are an important bioactive substructure in various bio-molecules having various biological activities [27]. In pharmaceutical chemistry, the thiourea skeleton plays a significant role. Derivatives of thiourea demonstrated strong cytotoxic activity against different cancer cells [28-31]. These compounds desirable inhibitory activity against different inhibitors plays a key role in the death of cancer cells [29-31]. In coordination chemistry, thiourea behaves as a flexible ligand because it can coordinate with a wide range of metal centers. Thiourea's applicability has also been successfully applied to its use as starting precursors in synthetic chemistry and the design of practical gas adsorption materials [32-34]. The emphasis of several review papers remained based on outstanding biological applications and efficiency of the thiourea class of 
compounds [35-37]. Synthesis and evaluation of new derivatives of thiourea as antitumor and anti-angiogenic agents has recently been published [38]. Many spectroscopic studies of thiourea derivatives have been reported by the author's community [39-42]. Molecular modeling techniques, especially the ones based on quantum mechanics and force fields, are very important tools for the initial investigation of newly synthesized molecules. Computational experiments have proven to be able to successfully predict local reactivity properties of the middle-sized organic molecules and in that way provide deeper insights into the underlying mechanism involving new molecules [43-46]. In this work, the combination of quantum mechanical and classical (force-field based) calculations have been used, to predict and understand reactivity and selected spectroscopic properties of FPTT molecule. In the present research, experimental and theoretical analysis of FPTT, with MD simulations are reported for finding different parameters like, identification of suitable excipients, interactions with water, and sensitivity towards autoxidation.

\section{Experimental details}

Synthesis of FPTT and spectral measurements (Figs. S1 and S2) are as in literature [1, $6,39,40]$. A solution of 3-(trifluoromethyl)aniline $(0.0031 \mathrm{~mol}, 0.50 \mathrm{~g})$ in dried acetonitrile $(10 \mathrm{~mL})$ was treated with 2-fluorophenylisothiocyanate $(0.0031 \mathrm{~mol})$ and the mixture was stirred at room temperature for $12 \mathrm{~h}$. Then the solvent was removed on rotary evaporator. The organic residue was purified by column chromatography (chloroform).

NMR $\left({ }^{1} \mathrm{H}\right.$ and $\left.{ }^{13} \mathrm{C}\right)$ for FPTT were recorded on $500 \mathrm{MHz}$ NMR Spectrometer. ${ }^{1} \mathrm{H}$ NMR $\delta: 10.14(\mathrm{~s}, 1 \mathrm{H}, \mathrm{NH}), 9.71(\mathrm{~s}, 1 \mathrm{H}, \mathrm{NH}), 7.98(\mathrm{~s}, 1 \mathrm{H}), 7.77(\mathrm{~d}, 1 \mathrm{H}), 7.60-7.53(\mathrm{~m}, 2 \mathrm{H})$, $7.46(\mathrm{~d}, 1 \mathrm{H}), 7.29-7.15(\mathrm{~m}, 3 \mathrm{H}) .{ }^{13} \mathrm{C}$ NMR $\delta: 180.79(\mathrm{C}=\mathrm{S}), 156.39,140.29(\mathrm{C} 2), 129.52$ (C6), 128.95 (C4), 128.62 (C11), 127.63 (C16), 127.27 (C1), 126.62 (C14), 124.24 (C15), 122.01 (C18), 120.72 (C3), 119.71 (C5), 116.01 (C13). HRMS (ESI) calc. [M - H] ${ }^{-}$: 313.0422, found: 313.0416 .

\section{Computational details}
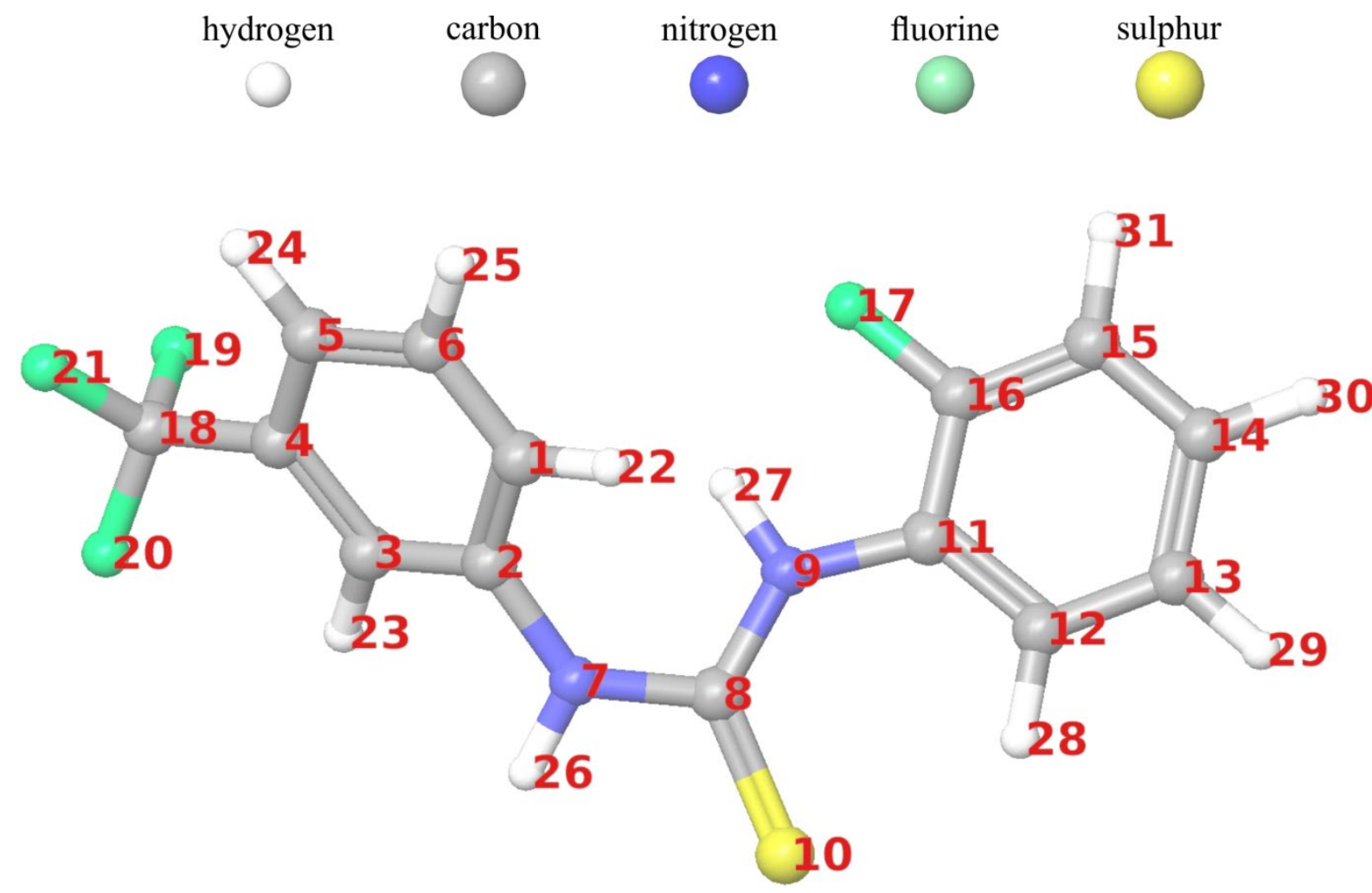

Fig.1 Optimized geometry of FPTT 
DFT/MO-5/6-311++G(d,p) is utilized for calculations of wavenumbers by Gaussian09 and Gaussview 5.0 [47-52]. Frequency calculations ensured optimized geometry (Fig.1) corresponds to a global minimum. Quantum mechanics and force field calculations in this research have been performed using the Schrodinger Suite 2020-4 (SMSS). When the SMSS package was used, a Jaguar [53-55] and Desmond [56,57] program was used for DFT and molecular dynamics . The main GUI of SMSS, Maestro [58], was used for input/output files. DFT calculations with Jaguar program have been performed with B3LYP exchangecorrelation functional, together with $6-31 \mathrm{G}(\mathrm{d}, \mathrm{p})$ and $6-311 \mathrm{G}(\mathrm{d}, \mathrm{p})$ basis sets [47, 59-61]. Single point energy calculations with the Jaguar program were used for obtaining information on molecular electrostatic potential (MEP) and average local ionization energy (ALIE) descriptors. Bond dissociation for the hydrogen abstraction has been performed with B3LYP/6-31G(d,p) level of theory. MD is a modeling method used to study the conformational rearrangement of molecules and their interactions with other molecular species in many environments. Regarding force field-based calculations, MD simulations have been performed by using OPLS3e force field [62-65] and for these simulations, the simulation time was set to $10 \mathrm{~ns}$, while other parameters included a temperature of $300 \mathrm{~K}$, normal pressure, and cut-off radius of $10 \AA$. In all MD simulations, the solvent was treated by a simple point charge (SPC) model [66]. MD simulations were used for understanding the interactions of FPTT with water and to obtain the solubility parameter. Further details on these calculations are provided in the corresponding chapters.

MD simulation of the PDBs, 2PSQ, 5AEP, and 2V3Q with FPTT is done by using GROMOS 53A6 force field of GROMACS simulation package 1-2. The molecular dynamics parameters and methods were followed as described earlier and the 50 ns simulation time was carried in a cube box of size $7.2 \times 11 \times 7.2 \mathrm{~nm}$ cuboid box. The RMSD of the backbone was analyzed in gromacs. The MM-PBSA method gives binding free energy ( $\Delta \mathrm{G}$ binding) of the ligand molecules with target proteins over simulation time. The last $20 \mathrm{~ns}$ were subjected to MMPBSA analysis [67-75]. Finally, to theoretically confirm the potential of the title molecule in terms of biological activity we have performed molecular docking study with the appropriate proteins with AutoDock-Vina software [76, 77].

\section{Results and discussion}

\subsection{Geometrical parameters}

The 1,3- and 1,2-disubstituted phenyl rings are termed as R1 and R2. C-C lengths

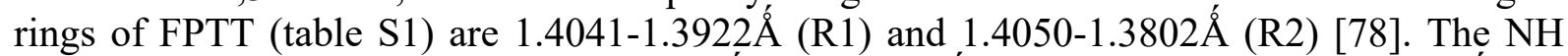
bond lengths in the present case are $1.0110 \AA$ and $1.0134 \AA$ [79]. $\mathrm{C}_{16}-\mathrm{F}_{17}$ length is $1.3630 \AA$ and $\mathrm{CF}_{3}$ lengths in the present case are $1.3526,1.3504,1.3505 \AA[80,81]$. The CCF and FCF angles in the $\mathrm{CF}_{3}$ group are $111.4,111.9,111.6^{\circ}$ and $106.9,107.1,107.6^{\circ}$, respectively [82].

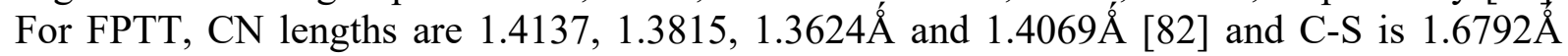
[79].

\subsection{IR and Raman spectra}

The vC-F (table 1) is normally at 1270-1100 $\mathrm{cm}^{-1}$ [83] and for FPTT, potential energy distribution (PED) analysis gives the vCF at $1198 \mathrm{~cm}^{-1}$ with $37 \%$ PED and experimentally bands are at $1209 \mathrm{~cm}^{-1}[84,85]$. The $\mathrm{CF}_{3}$ vibrational modes for FPTT are at $1178,1161,1129$ $\mathrm{cm}^{-1}$ (IR), 1168, 1156, $1133 \mathrm{~cm}^{-1}$ (Raman), 1173, 1155, $1121 \mathrm{~cm}^{-1}$ (DFT) [81, 86]. PED gives 38,65 and $41 \%$ for theoretical $v \mathrm{CF}_{3}, 1173,1155,1121 \mathrm{~cm}^{-1}$ with high IR intensities. $\delta \mathrm{CF}_{3}$ modes for FPTT are observed at $623,558 \mathrm{~cm}^{-1}$ (IR), 558, 368, $270 \mathrm{~cm}^{-1}$ (Raman) and assigned at $623,569,476,376,318,270 \mathrm{~cm}^{-1}$ (DFT) [81].

vNH are assigned at $3203 \mathrm{~cm}^{-1}$ (IR), $3212 \mathrm{~cm}^{-1}$ (Raman) and at $3507,3458 \mathrm{~cm}^{-1}$ (DFT) [86]. For vNH modes the PED value is around $100 \%$ with an IR intensity 59.38, 80.55 and Raman activity $162.97,181.95$. The $\delta \mathrm{NH}$ modes are at $1544,1492,591 \mathrm{~cm}^{-1}$ (IR), 1544, 
1492, 636, $588 \mathrm{~cm}^{-1}$ (Raman), 1529, 1478, 642, $590 \mathrm{~cm}^{-1}$ (DFT) with PEDs around 35\%. For FPTT, band at $724 \mathrm{~cm}^{-1}$ (IR), $726 \mathrm{~cm}^{-1}$ (Raman), $729 \mathrm{~cm}^{-1}$ (DFT) is assigned as $v \mathrm{C}=\mathrm{S}$ mode $[83,86,87]$ and reported modes are at $847,908 \mathrm{~cm}^{-1}$ [88]. Bands at 1267, $1178 \mathrm{~cm}^{-1}$ (IR), $1345,1242,1168 \mathrm{~cm}^{-1}$ (Raman) and 1341, 1268, 1232, $1173 \mathrm{~cm}^{-1}$ (DFT) are the vCN of FPTT [79].

Bands at $3135,3078 \mathrm{~cm}^{-1}$ (IR) and at $3130,3086 \mathrm{~cm}^{-1}$ (Raman) are the $v \mathrm{CH}$ modes of FPTT. Theoretical values are at 3095, 3091, 3079, $3074 \mathrm{~cm}^{-1}$ for R1 and 3139, 3104, 3102, $3089 \mathrm{~cm}^{-1}$ for R2 rings [86]. The bands at $1600,1318 \mathrm{~cm}^{-1}$ (IR), $1607,1465,1311 \mathrm{~cm}^{-1}$ (Raman), 1610-1319 $\mathrm{cm}^{-1}$ (DFT) and $1460 \mathrm{~cm}^{-1}$ (IR), 1593, 1447, 1345, $1311 \mathrm{~cm}^{-1}$ (Raman), in the range 1617-1306 $\mathrm{cm}^{-1}$ (DFT) are the ring $\mathrm{vCC}$ modes of R1 and R2 [86]. Ring breathing mode for FPTT is assigned at 964 and $1066 \mathrm{~cm}^{-1}$ theoretically [89-92]. For FPTT, $\delta \mathrm{CH}$ is at $1284,1267,1061,1026 \mathrm{~cm}^{-1}$ (IR) and at 1285, 1087, 1070, $1025 \mathrm{~cm}^{-1}$ (Raman). DFT values are at 1299-1054 $\mathrm{cm}^{-1}$ and $1262-1017 \mathrm{~cm}^{-1}$ ranges for R1 and R2 [86]. The $\gamma \mathrm{CH}$ modes of FPTT are at $889 \mathrm{~cm}^{-1}$ (IR), 959, 889, $785 \mathrm{~cm}^{-1}$ (Raman), 954, 894, 885, $778 \mathrm{~cm}^{-1}$ (DFT) and $750 \mathrm{~cm}^{-1}$ (IR), $750 \mathrm{~cm}^{-1}$ (Raman), 942, 906, 830, $748 \mathrm{~cm}^{-1}$ (DFT) for rings R1 and R2.

Aromatic protons have chemical shifts (ppm) in the range 7.54 to 7.88 for phenyl ring $\mathrm{R} 1$ and 6.97 to 8.81 to phenyl ring R2 theoretically. For the the NH groups, the shifts are 6.94 and 6.92 theoretically which shows deviations from experimental results, 10.14 and 9.72. For $\mathrm{C} 8$ atom the chemical shift is 177.65 theoreitcally while the experimental result is 180.79 . The carbon atoms in the ring R1, shows chemical shifts in the range 122.23 to 129.14 and for R2, the shifts are 116.80 to 153.77 theoretically. C16 and C18 show highest shifts of 153.77 and 132.90 due to the presence of fluorine atoms and the corresponding experiemental values are 156.40 and 132.90. The deviations of experimental and theoretical results are due to the following: theoretical calculations are in the gaseous phase while experimental resuls belong to solid phase.

\subsection{NBO, Chemical descriptors, and NLO properties}

Important interactions from NBO analysis [93,94] (tables S2 and S3, energy in $\mathrm{kcal} / \mathrm{mol})$ are:C12-C13 $\rightarrow \mathrm{BD}^{*}(\mathrm{C} 11-\mathrm{C} 16, \mathrm{C} 14-\mathrm{C} 15)(21.14,21.13), \mathrm{C} 11-\mathrm{C} 16 \rightarrow \mathrm{BD}^{*}(\mathrm{C} 12-$ $\mathrm{C} 13, \mathrm{C} 15-\mathrm{C} 14)(18.31, \quad 19.21), \mathrm{C} 15-\mathrm{C} 14 \rightarrow \mathrm{BD}^{*}(\mathrm{C} 12-\mathrm{C} 13, \mathrm{C} 11-\mathrm{C} 16)(19.26,21.36), \mathrm{C} 2-$ $\mathrm{C} 1 \rightarrow \mathrm{BD}^{*}(\mathrm{C} 6-\mathrm{C} 5, \mathrm{C} 4-\mathrm{C} 3)(19.15,20.35), \mathrm{C} 6-\mathrm{C} 5 \rightarrow \mathrm{BD} *(\mathrm{C} 2-\mathrm{C} 1, \mathrm{C} 4-\mathrm{C} 3)(21.39,21.31), \mathrm{C} 4-$ $\mathrm{C} 3 \rightarrow \mathrm{BD} *(\mathrm{C} 5-\mathrm{C} 1, \quad \mathrm{C} 6-\mathrm{C} 5)(19.75, \quad 20.05), \quad \mathrm{N} 9 \rightarrow \mathrm{BD} *(\mathrm{C} 11-\mathrm{C} 16, \quad \mathrm{C} 8-\mathrm{S} 10)(23.23, \quad 65.94)$, $\mathrm{S} 10 \rightarrow \mathrm{BD}^{*}(\mathrm{~N} 9-\mathrm{C} 8, \quad \mathrm{C} 8-\mathrm{N} 7)(12.09, \quad 10.26), \quad \mathrm{N} 7 \rightarrow \mathrm{BD}^{*}(\mathrm{C} 8-\mathrm{S} 10, \quad \mathrm{C} 2-\mathrm{C} 1)(66.58, \quad 16.35)$, $\mathrm{F} 19 \rightarrow \mathrm{BD}^{*}(\mathrm{C} 18-\mathrm{F} 21, \mathrm{C} 18-\mathrm{F} 20)(11.83,12.21), \mathrm{F} 21 \rightarrow \mathrm{BD}^{*}(\mathrm{C} 18-\mathrm{F} 19, \mathrm{C} 18-\mathrm{F} 20)(10.55,13.05)$, $\mathrm{F} 20 \rightarrow \mathrm{BD}^{*}(\mathrm{C} 18-\mathrm{F} 19, \mathrm{C} 18-\mathrm{F} 21)(10.35,13.12), \mathrm{F} 17 \rightarrow \mathrm{BD}^{*}(\mathrm{C} 11-\mathrm{C} 16)(18.94)$. 

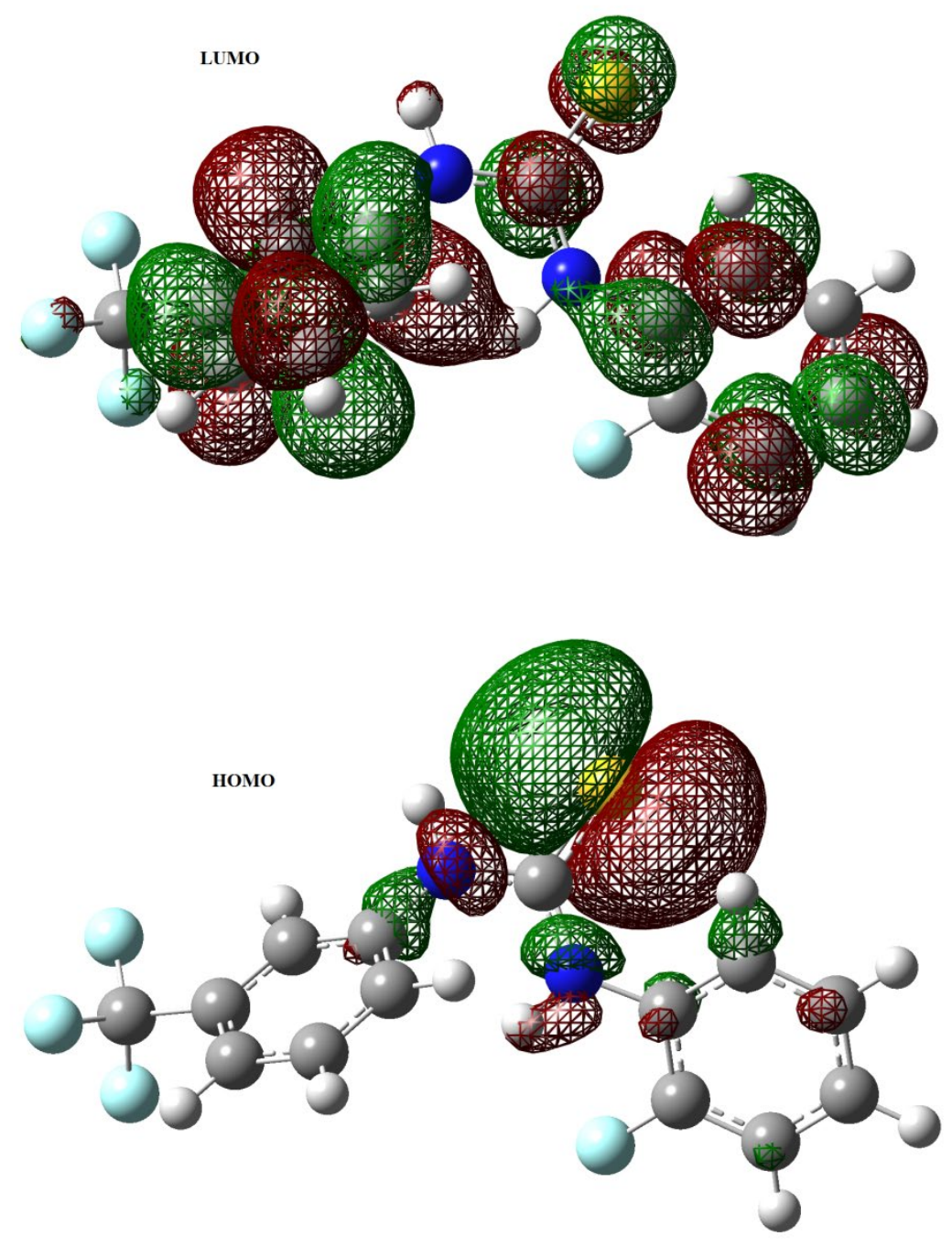

Fig.2 HOMO-LUMO plots of FPTT

The first-order hyperpolarizability of FPTT is $2.333 \times 10^{-30}$ which is 18 times that of urea and the second-order is $-16.688 \times 10^{-37}$ esu and polarizability is $2.153 \times 10^{-23}[95,96]$. The FMOs (Fig.2) associated molecular properties are, energy gap $(2.742 \mathrm{eV})$, ionization potential $(7.326 \mathrm{eV})$, electron affinity $(4.583 \mathrm{eV})$, chemical potential, $(-5.954 \mathrm{eV})$, hardness $(1.371 \mathrm{eV})$ and electrophilicity index $(12.929 \mathrm{eV})$. FPTT has an extremely high electrophilicity index value indicating bioactivity [97-99].

\subsection{MEP and ALIE surfaces}

Among many descriptors that are frequently used for the understanding of the local reactivity properties of organic molecules, MEP and ALIE are certainly some of the most important. Owing to their relation with the fundamental quantity in the DFT approach, electron density, these descriptors are the most frequently employed in computational studies to explain the local reactivity properties of studied molecules.

MEP descriptor is important because it gives information about the charge distribution, allowing one to identify whether effects of nuclei or electrons are dominant at points around the molecule. Thanks to this, the MEP descriptor indicates which parts of the molecule are sensitive to interactions with other molecules. The importance of the ALIE descriptor is due to its ability to show molecular sites in which the least amount of energy is 
required for the removal of an electron, and therefore for the ionization. Thanks to this, the ALIE descriptor indicates which parts of the molecule are sensitive to electrophilic attacks. The importance and usefulness of these descriptors have been indicated in many papers [100103].

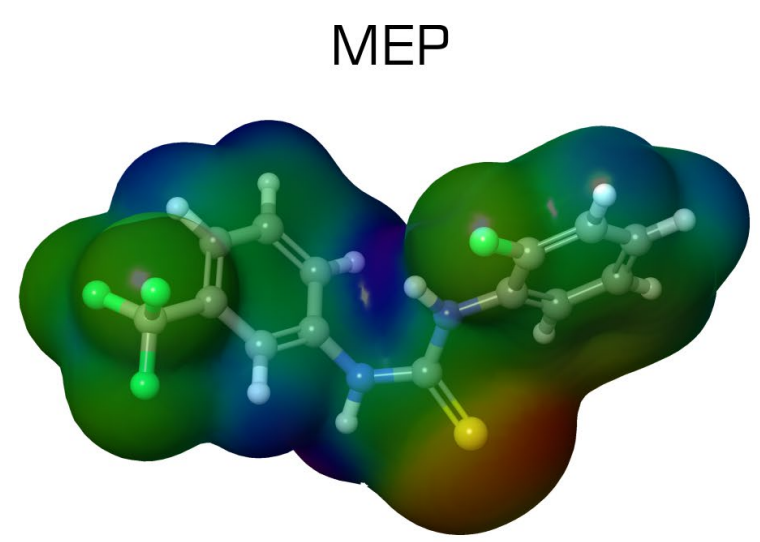

$-32.58$

40.52

Fig.3 MEP and ALIE surfaces of FPTT molecule, expressed in kcal/mol

For visualization in the case of MEP and ALIE descriptors, the best solution is to map their values to electron density surface, thanks to which one obtains so-called MEP and ALIE surfaces (Fig.3). According to Fig.3, the most reactive atom of all is the sulfur atom. This atom is characterized by the lowest MEP (-33 kcal/mol) and ALIE $(155 \mathrm{kcal} / \mathrm{mol})$ values, meaning that it is the most reactive with the other positively charged molecular species and that it is the most sensitive towards electrophilic attacks. The highest MEP values (41 $\mathrm{kcal} / \mathrm{mol}$ ) are for hydrogen belonging to the benzene ring, while the highest ALIE values $(382 \mathrm{kcal} / \mathrm{mol})$ are for chlorine.

\subsection{Sensitivity towards autoxidation}

One of the greatest concerns during the development of new drugs is the potential formation of genotoxic impurities, due to the sensitivity of active components to the autoxidation mechanism [104, 105]. Active components might have great biological activities, however, if they are sensitive to this mechanism, the whole project regarding the development of new pharmaceutical products might be unsuccessful.

From the experimental standpoint, determining the sensitivity of the drug candidate towards this mechanism might be very challenging. Therefore, it is imperative to search for theoretical means of how to predict the sensitivity of a molecule towards autoxidation. Luckily, it has been established that hydrogen-bond dissociation energy (H-BDE) is related to this important mechanism and that values of this parameter in the range between 70-85 $\mathrm{kcal} / \mathrm{mol}[106,107]$ most probably indicate that the studied molecule is sensitive towards autoxidation. Values $85-90 \mathrm{kcal} / \mathrm{mol}$ might indicate low sensitivity towards autoxidation, but in such cases, other parameters must also be taken into account. All H-BDE values for the FPTT molecule have been summarized in Fig.4. 


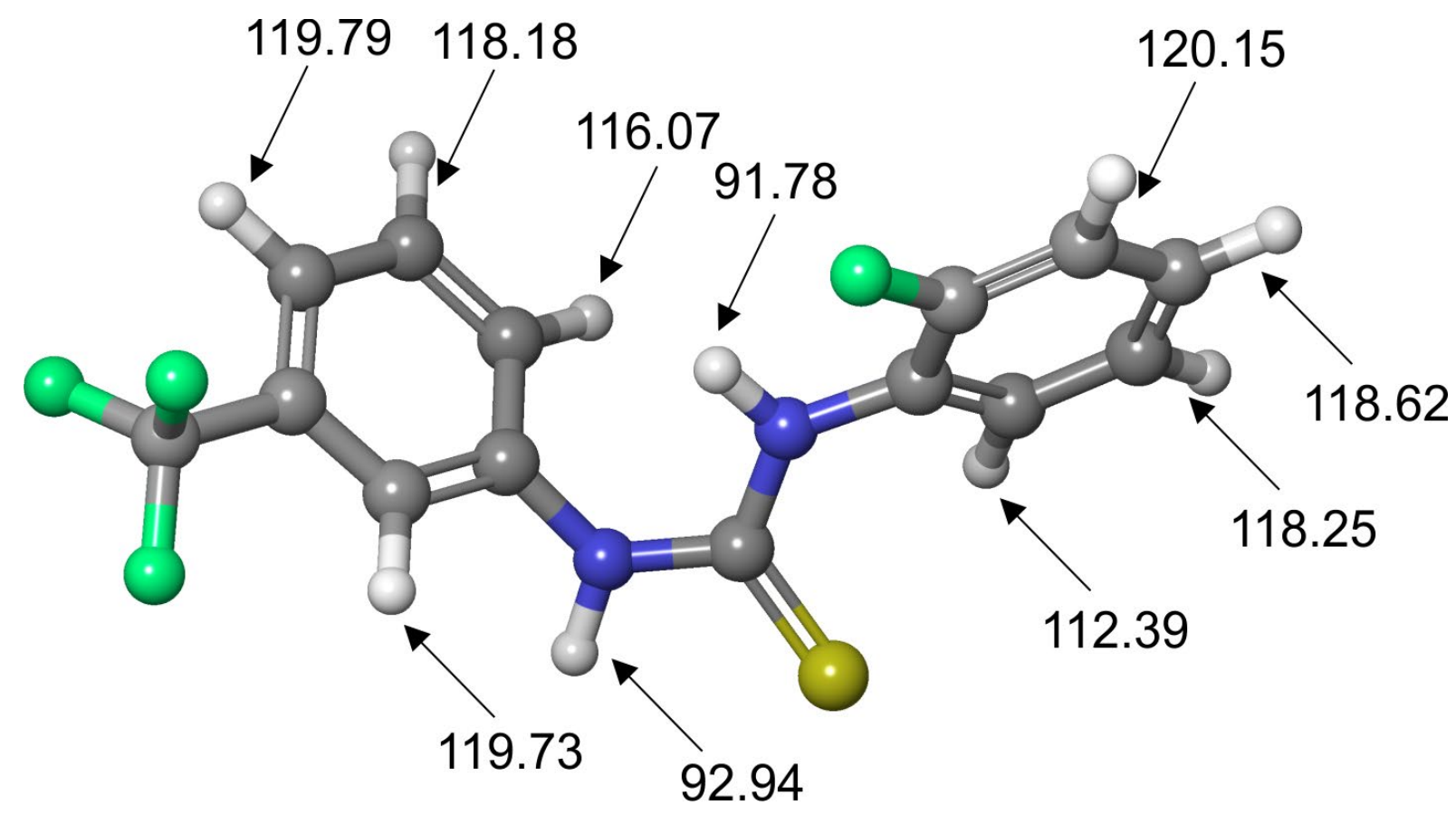

Fig.4 H-BDE values in case of FPTT molecule, expressed in $\mathrm{kcal} / \mathrm{mol}$

$\mathrm{H}-\mathrm{BDE}$ results presented (Fig.4) indicate that it is reasonable to expect that FPTT is highly stable towards the autoxidation mechanism. Of all calculated H-BDE values, only two of them are lower than $112 \mathrm{kcal} / \mathrm{mol}$. The two lowest values have been calculated for hydrogen connected to nitrogen, however, both of these values are higher than $90 \mathrm{kcal} / \mathrm{mol}$, indicating that FPTT should highly stable concerning the autoxidation mechanism.

\subsection{Interactions with water}

Thanks to the MD simulations, the interaction of FPTT with water was studied to identify atoms with relatively significant interactions with water molecules. This has been obtained by calculations of RDF, once the trajectories of all particles have been collected. RDFs have been calculated concerning the distance between the observed atom and oxygen of the water molecules. RDFs that can be considered as relatively important have been summarized in Fig.5. (Fig.S3 shows the formed noncovalent interactions between FPTT and water as obtained by DFT calculations). Molecules illustrated in ball and stick representation indicate water molecules with which our investigated molecule has formed noncovalent interactions, in that particular frame, according to the DFT calculations. Other water molecules surrounding the studied molecule have been illustrated in wire representation. Part of the MD frame presented in Fig. S3 indicates the importance of S atoms, as in this particular case, it formed noncovalent interactions with three water molecules. Results that can be seen in Fig. 5 that it is expected for the FPTT molecule to be highly stable in water. Namely, all of the calculated RDFs only the presented ones are having relatively sharp profiles, indicating relatively significant interactions with water. However, a closer analysis of these RDFs indicates that higher $\mathrm{g}(\mathrm{r})$ values are located at high distances, showing that water molecules are clustering at a high distance from the FPTT molecule. Namely, all of these higher $\mathrm{g}(\mathrm{r})$ values are located at distances much higher than $2 \AA$. The closed distance has been calculated for atom S10 (around 3.7 $\AA$ ). Carbon atom C6 is having a similar profile whose maximal $\mathrm{g}(\mathrm{r})$ value is located at a slightly higher distance. Maximal $g(r)$ value is highest in the case of the carbon atom $\mathrm{C} 18$, it is also located at the highest distance of more than $4 \AA$. 


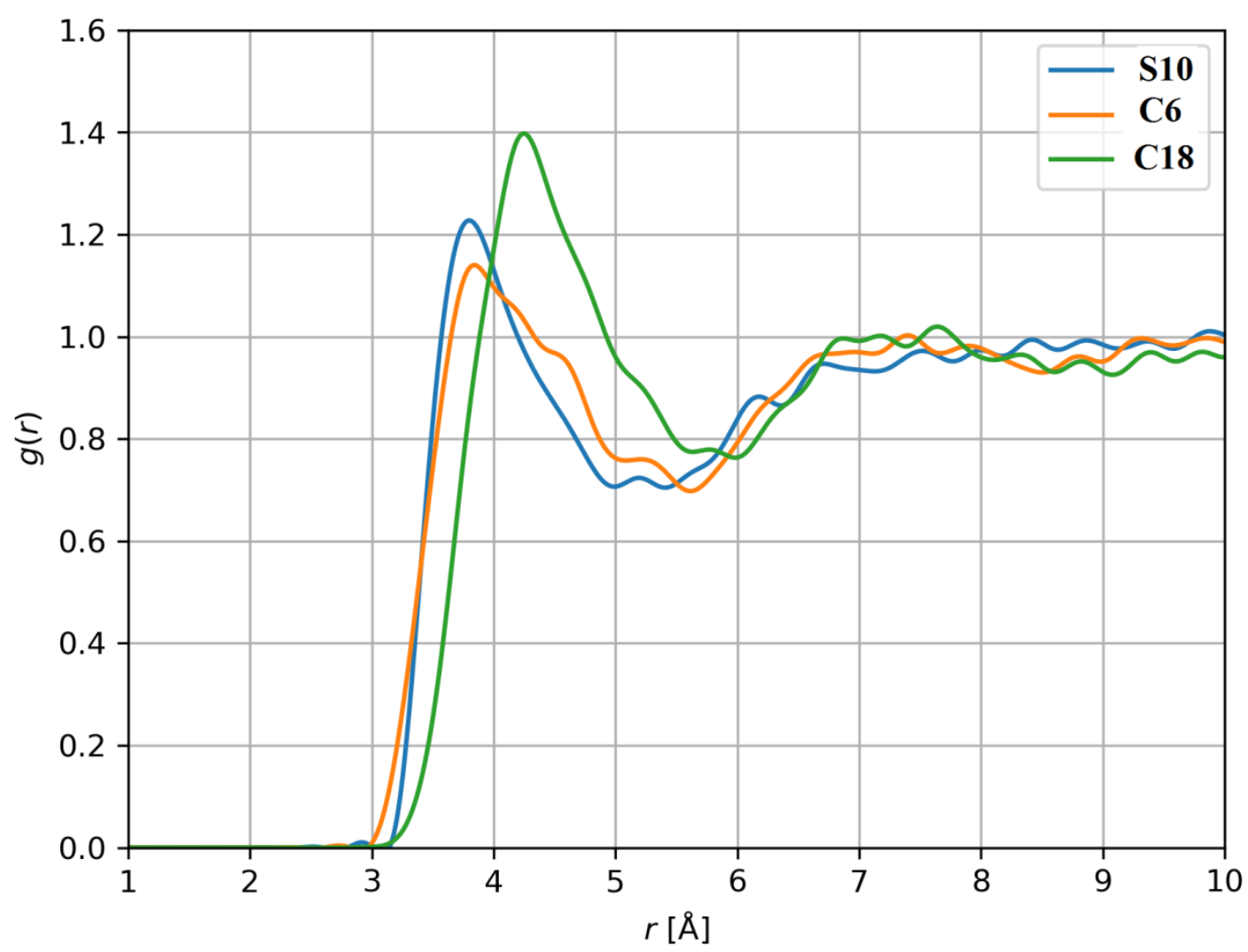

Fig.5 Selected RDFs of FPTT molecule

\subsection{Identification of suitable excipients}

Combining active components, possessing representative biochemical properties, with excipients is an important approach to improve their physical properties and enable practical applications. Namely, when it comes to the newly developed active components, it is frequently necessary to improve their stabilization, solubility, delivery properties, etc, and for these purposes, substances known as excipients are used. The number of substances that can be applied as excipients is high and it might be time-consuming to select the excipient which is compatible with the active component. Therefore, it is of industrial interest to identify computational methods that would allow suitable choices of excipients for newly developed active pharmaceutical components. In these regards, it has been established that active components and excipients are compatible if they possess similar values of solubility parameter [108-110]. On the other side, it is meaningful that the solubility parameter can be calculated computationally, via MD simulations by employing the following equation:

$$
\delta=\sqrt{\frac{\Delta H_{V}-R T}{V_{m}}} \text { (1) }
$$

In equation (1), $\Delta H_{V}$, and $\mathrm{V}_{\mathrm{m}}$ are the heat of vaporization and molar volume. MD simulation model that has been used for calculation of solubility parameter consisted of 32 FPTT molecules placed in the cubic simulation box. The mentioned system for simulated in NPT regime for the simulation time of $10 \mathrm{~ns}$, employing the OPLS3e force field. In the case of FPTT, the above-mentioned equation yielded the value of the solubility parameter to be 21.521 $\mathrm{MPa}^{1 / 2}$. To make this value useful, we have performed the MD simulations in the same setup for the frequently used excipients, such as polyvinylpyrrolidone polymer (PVP), 
maltose, and sorbitol. Solubility parameters for FPTT and mentioned, frequently used, excipients have been summarized in table 2 .

Table 2. Values of solubility parameters $\delta\left[\mathrm{MPa}^{1 / 2}\right]$ for FPTT and selected excipients

\begin{tabular}{|l|l|}
\hline Molecules & $\delta\left[\mathrm{MPa}^{1 / 2}\right]$ \\
\hline FPTT & 20.521 \\
\hline PVP & 18.515 \\
\hline Maltose & 28.564 \\
\hline Sorbitol & 32.425 \\
\hline
\end{tabular}

\subsection{Molecular docking and MD simulations}

Receptors of the growth factor increased expression and activation of receptor tyrosine kinases frequently occurs in carcinomas of the human breast. Docking was done on Auto Dock-Vina [76, 77] using the proteins, 2PSQ, 5AEP, 2V3Q with predicted activities (table S4), Platelet-derived growth factor receptor kinase inhibitor, Phobic disorders treatment and Atherosclerosis treatment activities [111]. Different methods targeting these receptors are in clinical research studies $[112,113]$. Several literature surveys show that thiourea derivatives as anticancerous $[114,115]$. Thus we choose FPTT as ligand and selected inhibitors as the target. Fig.S4 and Fig.S5 demonstrate docked ligand at the active site of receptors. The docked ligand forms stable complexes with binding affinities of $-7.7,-8.4$, and $-7.0 \mathrm{kcal} / \mathrm{mol}$ (Table 3). As a result, FPTT demonstrates activity against these inhibitors and may be used as new drugs. The inhibition is a function of binding modes and affinities of molecules to enzymes [116].

Table 3 Docking analysis of receptors with ligands

\begin{tabular}{|l|l|l|l|l|}
\hline $\begin{array}{l}\text { Receptors } \\
\text { name }\end{array}$ & $\begin{array}{l}\text { Binding } \\
\text { energy }\end{array}$ & $\begin{array}{l}\text { Residues involved in } \\
\text { hydrogen bonding }\end{array}$ & $\begin{array}{l}\text { Residues involved in } \\
\text { electrostatic } \\
\text { interactions }\end{array}$ & $\begin{array}{l}\text { Residues involved in } \\
\text { hydrophobic } \\
\text { interactions }\end{array}$ \\
\hline 2PSQ & -7.7 & $\begin{array}{l}\text { ASP644, LYS517, } \\
\text { VAL495, ALA515, } \\
\text { LEU633 }\end{array}$ & $\begin{array}{l}\text { LYS517, GLU565, } \\
\text { ASP644 }\end{array}$ & $\begin{array}{l}\text { VAL495, ALA515, } \\
\text { VAL564, LEU633, } \\
\text { LEU487, }\end{array}$ \\
\hline 5AEP & -8.4 & $\begin{array}{l}\text { ARG980, LEI392, } \\
\text { ASP994, LEU983, } \\
\text { ALA880, }\end{array}$ & $\begin{array}{l}\text { LEU392, ASP994, } \\
\text { ASN981, }\end{array}$ & $\begin{array}{l}\text { LEU392, LEU983, } \\
\text { MET929, LEU885, } \\
\text { ALA880, VAL863, } \\
\text { TYR931 }\end{array}$ \\
\hline 2V3Q & -7.0 & $\begin{array}{l}\text { PRO260, LEU261, } \\
\text { LYS63, ASP271, }\end{array}$ & $\begin{array}{l}\text { LYS63, PRO260, } \\
\text { ASP271, VAL274, } \\
\text { GLY283, GLY284, }\end{array}$ & $\begin{array}{l}\text { PRO260, GLY284, } \\
\text { VAL272, TRP346, }\end{array}$ \\
\hline
\end{tabular}

Fig.S6 displays the RMSD outcome of the 2PSQ, 5AEP, 2V3Q and FPTT complex. The 2PSQ, 2V3Q and 5AEP complex with FPTT structures were stable after 30, 20 and $30 \mathrm{ns,}$ respectively. Average values and standard deviations of 2PSQ, 2V3Q, 5AEP complex with FPTT are respectively, $\sim 0.211+/-0.025, \sim 0.238+/-0.035$ and $\sim 0.241+/-0.030 \mathrm{~nm}$ of $50 \mathrm{~ns}$ 
simulation. This reflects protein-FPTT maintain for the entire simulation time stability. MMPBSA values give binding free energy values of 2PSQ, 2V3Q and 5AEP with FPTT are respectively, $-31.429+/-3.956,-27.908+/-3.297$, and $-26.886+/-3.500 \mathrm{kcal} / \mathrm{mol}$ which means inhibitor has better energy with all the targets (Table 4).

Table 4. MMPBSA value of EGFR target of 50ns simulation

\begin{tabular}{|l|l|l|}
\hline PDB ID & Ligand & Binding energy \\
\hline 2PSQ & FPTT & $-31.429+/-3.956 \mathrm{kcal} / \mathrm{mol}$ \\
\hline 2V3Q & FPTT & $-27.908+/-3.297 \mathrm{kcal} / \mathrm{mol}$ \\
\hline 5 AEP & FPTT & $-26.886+/-3.500 \mathrm{kcal} / \mathrm{mol}$ \\
\hline
\end{tabular}

\section{Conclusion}

Combinations of DFT and MD simulations were used to identify the most important reactive sites of FPTT. In these regards, both MEP and ALIE surfaces revealed that the most important reactive atom might be sulfur since this atom is characterized by the lowest MEP and ALIE values. Calculations of the H-BDE parameter indicate that FPTT should be highly resistant to the autoxidation mechanism since DFT calculations showed that all $\mathrm{H}-\mathrm{BDE}$ values are higher. This also indicates that FPTT could be stable during the shelf life and that the formation of genotoxic impurities should not occur. MD simulations identified which atoms have relatively pronounced interactions with water molecules. Analysis of RDFs MD simulations showed that three atoms (S10, C6, and C18) are having significant interactions with water. However, the overall influence of water is low, because in all cases the higher $\mathrm{g}(\mathrm{r})$ values are at high distances. Solubility parameters for FPTT and selected excipients have been calculated also by the application of MD simulations. It was found that the solubility parameter of FPTTis the closest to the PVP, meaning that this combination might have the potential for the development of novel pharmaceutical products. Validation by MD integrated with molecule interactions shows stability with the target proteins.

\section{Ethics declarations \\ Funding}

The authors, SA and SJA acknowledge the financial support of the Ministry of Education, Science and Technological Development of the Republic of Serbia (Grant No. 451-0368/2020-14/200125).

\section{Author's contributions}

All authors contributed to the study conception and design. Material preparation, data collections and analysis were performed by Y.Sheena Mary, Y.Shyma Mary, Stevan Armaković, Sanja J. Armaković, Vivek Chandramohan, Manjunath Dammalli. Experimental part is done by Anna Bielenica.

\section{Conflict of interest}

The authors declare that they have no conflict of interest.

\section{Ethics approval}

The manuscript is prepared in compliance with the Ethics in Publishing Policy as described in the Guide for Authors

\section{Consent to participate}

The manuscript is approved by all authors for publication

\section{Consent for publication}


The consent for publication was obtained from all participants

\section{Code availability}

The calculations have been carried out using Gaussian09 and Gaussview version provided by Gaussian Inc., Schrodinger Suite 2020-4, GROMACS.

\section{Acknowledgments}

VC, thank KBITS, Bangalore and BiSEP (Department of Biotechnology, Siddaganga Institute of Technology, Tumakuru), Karnataka.

\section{References}

1. Bielenica A, Stefańska J, Stępień K, Napiórkowska A, Augustynowicz-Kopeć E, Sanna G, Madeddu S, Boi S, Giliberti, G, Wrzosek M, Struga M (2015) Synthesis, cytotoxicity and antimicrobial activity of thiourea derivatives incorporating 3(trifluoromethyl)phenyl moiety. Eur J Med Chem 101:111-125. https://doi.org/10.1016/j.ejmech.2015.06.027

2. Bielenica A, Stępień K, Napiórkowska A, Augustynowicz-Kopeć, E, Krukowski S, Włodarczyk M, Struga M (2016) Synthesis and antimicrobial activity of 4-chloro-3nitrophenylthiourea derivatives targeting bacterial type II topoisomerases. Chem Biol Drug Des 87:905-917. https://doi.org/10.1111/cbdd.12723

3. Sriram D, Yogeeswari P, Dinakaran M, Thirumurugan R (2007) Antimycobacterial activity of novel 1-(5-cyclobutyl-1,3-oxazol-2-yl)-3-(sub)phenyl/pyridylthiourea compounds endowed with high activity toward multidrug resistant mycobacterium tuberculosis. J Antimicrob Chemother 59:1194-1196. https://doi.org/10.1093/jac/dkm085

4. Bhowruth V, Brown AK, Reynolds RC, Coxon GD, Mackay SP, Minnikin DE, Besra GS (2006) Symmetrical and unsymmetrical analogues of isoxyl active agents against mycobacterium tuberculosis. Bioorg Med Chem Lett 16:4743-4747. https://doi.org/10.1016/j.bmcl.2006.06.095

5. Mishra A, Batra S (2013) Thiourea and guanidine derivatives as antimalarial and antimicrobial agents. Curr Top Med Chem 13:2011-2025. https://doi.org/10.2174/1568026611319990126

6. Vega-Pérez JM, Periñán I, Argandoña M, Vega-Holm, M, Palo-Nieto C, BurgosMorón E, López-Lázaro M, Vargas C, Nieto JJ, Iglesias-Guerra F (2012) Isoprenyl thiourea and urea derivatives as new farnesyl diphosphate analogues, synthesis and in vitro antimicrobial and cytotoxic activities. Eur J Med Chem 58:591-612. https://doi.org/10.1016/j.ejmech.2012.10.042

7. Kumbhare RM, Dadmal T, Kosurkar U, Sridhar V, Rao JV (2012) Synthesis and cytotoxic evaluation of thiourea and N-bis-benzothiazole derivatives: A novel class of cytotoxic agents. Bioorg Med Chem Lett 22:453-455. https://doi.org/10.1016/j.bmcl.2011.10.106

8. Bielenica A, Kędzierska E, Koliński M, Kmiecik S, Koliński A, Fiorino F, Severino B, Magli E, Corvino A, Rossi I, Massarelli P, Kozioł AE, Sawczenko A, Struga M (2016) 5-HT2 receptor affinity, docking studies and pharmacological evaluation of a series of 1,3-disubstituted thiourea derivatives. Eur J Med Chem 116:173-186. https://doi.org/10.1016/j.ejmech.2016.03.073

9. Bielenica A, Kedzierska E, Fidecka S, Maluszynska H, Miroslaw B, Koziol AE, Stefanska J, Madeddu S, Giliberti G, Sanna G, Struga M (2015) Synthesis, antimicrobial and pharmacological evaluation of thiourea-derivatives of $4 \mathrm{H}-1,2,4-$ triazole. Lett Drug Des Discov 12:263-276. https://doi.org/10.2174/1570180811666141001010044

10. Struga M, Kossakowski J, Koziol AE, Lis T, Kedzierska E, Fidecka S (2009) Synthesis and pharmacological activity of thiourea derivatives of 1,7,8,9-tetramethyl- 
4-azatricyclo[5.2.1.02,]dec-8-ene-3,5-dione. Lett Drug Des Discov 6:445-450. https://doi.org/10.2174/157018009789057517

11. Stefanska J, Szulczyk D, Koziol AE, Miroslaw B, Kedzierska E, Fidecka S, Busonera B, Sanna G, Giliberti G, La Colla P, Struga M (2012) Disubstituted thiourea derivatives and their activity on CNS, synthesis and biological evaluation. Eur J Med Chem 55:205-213. https://doi.org/10.1016/j.ejmech.2012.07.020

12. Struga M, Kossakowski J, Kedzierska E, Fidecka S, Stefańska J (2007) Synthesis and pharmacological activity of urea and thiourea derivatives of 4-azatricyclo[5.2.2.0, 2,6]undec-8-ene-3,5-dione. Chem Pharm Bull (Tokyo) 55:796-799. https://doi.org/10.1248/cpb.55.796

13. Suresh GP, Suhas R, Kapfo W, Gowda DC (2011) Urea/thiourea derivatives of quinazolinone-lysine conjugates: synthesis and structure activity relationships of a new series of antimicrobials. Eur J Med Chem 46:2530-2540. https://doi.org/10.1016/j.ejmech.2011.03.041

14. Chikhalia KH, Patel MJ (2009) Design, synthesis and evaluation of some 1,3,5triazinyl urea and thiourea derivatives as antimicrobial agents. J Enzym Inhib Med Chem 24:960-966. https://doi.org/10.1080/14756360802560966

15. Li WQ, Wang XL, Qian K, Liu YQ, Wang CY, Yang L, Tian J, Morris- Natschke SL, Zhou XW, Lee KH (2013) Design, synthesis and potent cytotoxic activity of novel popophylotoxin derivatives. Bioorg Med Chem 21:2363-2369. https://doi.org/10.1016/j.bmc.2013.01.069

16. Koca I, Ozgür A, Cos KA, Tutar Y (2013) Synthesis and anticancer activity of acyl thioureas bearing pyrazole moiety. Bioorg Med Chem 21:3859-3865. https://doi.org/10.1016/j.bmc.2013.04.021

17. Karakuş S, GünizKüçükgüzel S, Küçükgüzel I, De Clercq E, Pannecouque C, Andrei G, Snoeck R, Sahin F, Bayrak OF (2009) Synthesis, antiviral and anticancer activity of some novel thioureas derived from N-(4-nitro-2-phenoxyphenyl)methanesulfonamide. Eur $J$ Med Chem 44:3591-3595. https://doi.org/10.1016/j.ejmech.2009.02.030

18. Di Grandi MJ, Curan KJ, Feigelson G, Prashad A, Ross AA, Visalli R, Fairhurst J, Feld B, Bloom JD (2004) Thiourea inhibitors of herpesviruses, part 3. Inhibitors of varicella zoster virus. Bioorg Med Chem Lett 14:4157-4160. https://doi.org/10.1016/j.bmcl.2004.06.025

19. Bloom JD, DiGrandi MJ, Dushin RG, Curran KJ, Ross AA, Norton EB, Terefenko E, Jones TR, Feld B, Lang SA (2003) Thiourea inhibitors of herpes viruses, part 1, bis(aryl)thiourea inhibitors of CMV. Bioorg Med Chem Lett 13:2929-2932. https://doi.org/10.1016/S0960-894X(03)00586-9

20. Khan MT, Ather A, Thompson KD, Gambari R (2005) Extracts and molecules from medicinal plants against herpes simplex viruses. Antivir Res 67:107-119. https://doi.org/10.1016/j.antiviral.2005.05.002

21 Ren J, Diprose J, Warren J, Esnouf RM, Bird LE, Ikemizu S, Slater M, Milton J, Balzarini J, Stuart DI, Stammers DK (2000) Phenylethylthiazolylthiouread (PETT) non-nucleoside inhibitors of HIV-1 and HIV-2 reverse transcriptases. J Biol Chem 275:5633-5639. https://doi.org/10.1074/jbc.275.8.5633

22. Abu-Melha S (2013) Synthesis and antimicrobial activity of some new heterocycles incorporating the pyrazolopyridine moiety. Arch Pharm Weinheim 346:912-921. https://doi.org/10.1002/ardp.201300195

23. Yang W, Liu H, Li M, Wang F, Zhou W, Fan J (2012) Synthesis, structures and antibacterial activities of benzyolthiourea derivatives and their complexes with cobalt. J Inorg Biochem 116:97-105. https://doi.org/10.1016/j.jinorgbio.2012.08.001 
24. Plutín AM, Mocelo R, Alvarez A, Ramos R, Castellano EE, Cominetti MR, Graminha AE, Ferreira AG, Batista AA (2014) On the cytotoxic activity of Pd(II) complexes of N,N-disubstituted-N'-acyl thioureas. J Inorg Biochem 134:76-82. https://doi.org/10.1016/j.jinorgbio.2014.01.022

25. Arslan H, Duran N, Borekci G, Koray Ozer C, Akbay C (2009) Antimicrobial activity of some thiourea derivatives and their nickel and copper complexes. Molecules 14:519-527. https://doi.org/10.3390/molecules14010519

26. Batey RA, Powell DA (2000) A general synthetic method for the formation of substituted 5-aminotetrazoles from thioureas, a strategy of diversity amplification. Org Lett 2:3237-3240. https://doi.org/10.1021/o1006465b

27. Min LJ, Zhai ZW, Shi YX, Han L, Tan CX, Weng JQ, Li BJ, Zhang YG, Liu XH (2020) Synthesis and biological activity of acyl thiourea containing difluoromethyl pyrazole motif. Phosphorus, Sulfur, and Silicon and the Related Elements 195:22-28. https://doi.org/10.1080/10426507.2019.1633530

28. Eshkil F, Eshghi H, Saljooghi AS, Bakavoli M, Rahimizadeh M (2017) Benzothiazole thiourea derivatives as anticancer agents: Design, synthesis and biological screening. Russian J Bioorg Chem 43:576-582. https://doi.org/10.1134/S10681620017050065

29. Moeker J, Teruya K, Rossit S, Wilkinson BL, Lopez M, Bornaghi LF, Innocenti A, Supuran CT, Poulsen SA (2012) Design and synthesis of thiourea compounds that inhibit transmembrane anchored carbonic anhydrases. Bioorg Med Chem 20:23922404. https://doi.org.10.1016/j.bmc.2012.01.052

30. Sun Y, Shan Y, Li C, Si R, Pan X, Wang B, Zhang J (2017) Discovery of novel antiangiogenesis agents. Part 8: Diaryl thiourea bearing $1 \mathrm{H}$-indazole-3-amine as multitarget RTKs inhibitors. Eur J Med Chem 141:373-385. https://doi.org/10.1016/j.ejmech.2017.10.008

31. Alimohammadi A, Mostafavi H, Mahdavi M (2020) Thiourea derivatives based on the dapsone-naphthoquinone hybrid as anticancer and antimicrobial agents: In vitro screening and molecular docking studies. Chemistry Select 5:847-852. https://doi.org/10.1002/slct.201903179

32. Saeed A, Qamar R, Fattah TA, Florke U, Erben MF (2017) Recent developments in Chemistry, coordination, structure and biological aspects of 1-(acyl/aroyl)-3(substituted)thioureas. Res Chem Intermed 43:3053-3093. https://doi.org/10.1007/s11164-016-2811-5

33. Markov SV, Horvath AK, Silaghi-Dumitrescu R, Gao Q (2014) Recent developments in chemistry of thiourea oxides. Chemistry 20:14164-14176. https://doi.org/10.1002/chem.201403453

34. Tian Z, Lai F, Heil T, Cao S, Antonietti, M (2020) Synthesis of carbon frameworks with $\mathrm{N}, \mathrm{O}$ and $\mathrm{S}$-linked pores from gallic acid and thiourea for superior $\mathrm{CO} 2$ adsorption and supercapacitors. Sci China Mater 63:748-710. https://doi.org/10.1007/s40843-019-1254-9

35. Shakeel A, Altaf AA, Qureshi AM, Badshah A (2016) Thiourea derivatives in drug design and medicinal chemistry: A short review. J Drug Des Med Chem 2:10-20 https://doi.org/10.11648/j.jddmc.20160201.12

36. Saeed A, Mustafa MN, Zain-Ul-Abideen M, Shabir G, Erben MF, Florke U (2019) Current developments in chemistry, coordination, structure and biological aspects of 1-(acyl/aroyl)-3-(substituted)thioureas: advances continue .... Sulfur Chem 40:312350. https://doi.org/10.1080/17415993.2018.1551488

37. Khan E, Khan S, Gul Z, Muhammad M (2020) Medicinal importance, coordination chemistry with selected metals $(\mathrm{Cu}, \mathrm{Ag}, \mathrm{Au})$ and chemosensing of thiourea 
derivatives, A review. Critical Reviews in Analytical Chemistry https://doi.org/10.1080/10408347.2020.1777523

38. Bai W, Ji J, Huang Q, Wei W (2020) Synthesis and evaluation of new thiourea derivatives as antitumor and antiangiogenic agents. Tetrahedron Lett 61:152366. https://doi.org/10.1016/j.tetlet.2020.152366

39. Menon VV, Mary YS, Mary YS, Panicker CY, Bielenica A, Armakovic S, Armakovic SJ, Van Alsenoy C (2018) Combined spectroscopic, DFT, TD-DFT and MD study of newly synthesized thiourea derivative. J Mol Struct 1155:184-195. https://doi.org/10.1016/j.molstruc.2017.10.093

40 Aswathy VV, Mary YS, Jojo PJ, Panicker CY, Bielenica A, Armakovic S, Armakovic SJ, Brozka P, Krukowski S, Van Alsenoy C (2017) Investigation of spectroscopic, reactive, transport and docking properties of 1-(3,4-dichlorophenyl)-3-[3(trifluoromethyl)phenyl]thiourea (ANF:6): Combined experimental and computational study. J Mol Struct 1134:668-680. https://doi.org/10.1016/j.molstruc.2017.01.016

41. War JA, Jalaja K, Mary YS, Panicker CY, Armakovic S, Armakovic SJ, Srivastava SK, Van Alsenoy C (2017) Spectroscopic characterization of 1-[3-(1H-imidaozl-1yl)propyl]-3-phenylthiourea and assessment of reactive and optoelectronic properties employing DFT calculations and molecular dynamics simulations. J Mol Struct 1129:72-85. https://doi.org/10.1016/j.molstruc.2016.09.063

42. Mary YS, Aswathy VV, Panicker CY, Bielenica A, Brzozka P, Savczenko O, Armakovic S, Armakovic SJ, Van Alsenoy C (2016) Spectroscopic, single crystal XRD structure, DFT and molecular dynamics investigation of 1-(3-chloro-4fluorophenyl)-3-[3-(trifluoromethyl)phenyl]thiourea. RSC Adv 6:111997-112015. https://doi.org/10.1039/C6RA21396K

43. Armakovic S, Armakovic SJ, Koziel S (2017) Optoelectronic properties of curved carbon systems. Carbon 111:371-379. https://doi.org/10.1016/j.carbon.2016.10.022

44. Murthy PK, Suneetha V, Smitha M, Mary YS, Armakovic S, Armakovic SJ, Rao RS, Suchetan PA, Al-Saadi AA, Pavithran R (2019) Synthesis, conformational, characterization and reactivity study of 1,7-bis(4-bromophenyl)heptanes-1,7-dione. J Mol Struct 1175:269-279. https://doi.org/10.1016/j.molstruc.2018.08.003

45. Prasad KS, Pillai RR, Armakovic S, Armakovic SJ (2019) Photophysical properties and theoretical investigations of newly synthesized pyrene-naphthalene based Sciff base ligand and its copper(II) complexes. Inorganica Chim Acta 486:698-703 https://doi.org/10.1016/j.ica.2018.11.045

46. Tomic BT, Abraham CS, Pelemis S, Armakovic SJ, Armakovic S (2019) Fullerene C24 as a potential carrier of ephedrine drug-a computational study of interactions and influence of temperature. Phys Chem Chem Phys 21:23329-23337. https://doi.org/10.1039/c9cp04534a

47 Becke AD (1993) Density functional thermochemistry. III. The role of exact exchange. J Chem Phys 98:5648-5652. https://doi.org/10.1063/1.464913

48. Becke AD (1988) Density functional exchange energy approximation with correct asymptotic behaviour. Phys Rev A 38:3098-3100. https://doi.org/10.1103/PhysRevA.38.3098

49. Foresman JB, Frisch E (1996) Exploring Chemistry with Electronic Structure Methods: A Guide to Using Gaussian, Pittsburg, PA.

50. Dennington R, Keith T, Millam J (2009) Gaussview, Version 5, Semichem Inc., ShawneeMission, KS.

51. Gaussian 09, Revision B.01, Frisch MJ, Trucks GW, Schlegel HB, Scuseria GE, Robb MA, Cheeseman JR, Scalmani G, Barone V, Mennucci B, Petersson GA, Nakatsuji H, Caricato M, Li X, Hratchian HP, Izmaylov AF, Bloino J, Zheng G, Sonnenberg JL, 
Hada M, Ehara M, Toyota K, Fukuda R, Hasegawa J, Ishida M, Nakajima T, Honda Y, Kitao O, Nakai H, Vreven T, Montgomery Jr JA, Peralta JE, Ogliaro F, Bearpark M, Heyd JJ, Brothers E, Kudin KN, Staroverov VN, Keith T, Kobayashi R, Normand J, Raghavachari K, Rendell A, Burant JC, Iyengar SS, Tomasi J, Cossi M, Rega N, Millam JM, Klene M, Knox JE, Cross JB, Bakken V, Adamo C, Jaramillo J, Gomperts R, Stratmann RE, Yazyev O, Austin AJ, Cammi R, Pomelli C, Ochterski JW, Martin RL, Morokuma K, Zakrzewski VG, Voth GA, Salvador P, Dannenberg JJ, Dapprich S, Daniels AD, Farkas O, Foresman JB, Ortiz JV, Cioslowski J, Fox DJ (2010) Gaussian, Inc., Wallingford CT.

52. Martin JML, Van Alsenoy C (2007) GAR2PED, a Program to Obtain a Potential Energy Distribution from a Gaussian Archive Record, University of Antwerp, Belgium.

53. Bochevarov AD, Harder E, Hughes TF, Greenwood JR, Braden DA, Philipp DM, Rinaldo D, Halls MD, Zhang J, Friesner RA (2013) Jaguar: A high performance quantum chemistry software program with strengths in life and materials sciences. Int J Quantum Chem 113:2110-2142. https://doi.org/10.1002/qua.24481

54. Jacobson LD, Bochevarov AD, Watson MA, Hughes TF, Rinaldo D, Ehrlich S, Steinbrecher TB, Vaitheeswaran S, Philipp DM, Halls MD (2017) Automated transition state search and its application to diverse types of organic reactions. J Chem Theory Comput 13:5780-5797. https://doi.org/10.1021/acs.jctc. $7 b 00764$

55. Schrodinger Release 2020-3: Jaguar, Schrodinger, LLC, New York, NY, 2020 (n.d.).

56. Bowers KJ, Chow DE, Xu H, Dror RO, Eastwood MP, Gregeersen BA, Klepeis JL, Kolossvary I, Moraes MA, Sacerdoti FD (2006) Scalable algorithms for molecular dynamics simulations on commodity clusters, in: SC'06 Proc. 2006 ACM/IEEE Conf. Supercomput. IEEE, p.43.

57. Schrodinger Release 2020-3: Desmond Molecular Dynamics System, DE.Shaw Research, New York, NY, 2020. Maestro-Desmond Interoperability Tools, Schrodinger, New York, NY, 2020. (n.d.).

58. Schrodinger Release 2020-3: Maestro, Schrodinger, LLC, New York, NY, 2020 (n.d.)

59 Lee C, Yang W, Parr RG (1988) Development of the Colle-Salvetti correlation-energy formula into a functional of the electron density. Phys Rev B 37:785-789. https://doi.org/10.1103/PhysRevB.37.785

60. Vosko SH, Wilk L, Nusair M (1980) Accurate spin-dependent electron liquid correlation energies for local spin density calculations: a critical analysis. Can J Phys 58:1200-1211. https://doi.org/10.1139/p80-159

61. Stephens PJ, Devlin FJ, Chabalowski CF, Frisch MJ (1994) Ab initio calculation of vibrational absorption and circular dichroism spectra using density functional force fields. J Phys Chem 98:11623-11627. https://doi.org/10.1021/j100096a001

62. Harder E, Damm W, Maple J, Wu C, Reboul M, Xiang JY, Wang L, Lupyan D, Dahlgren MK, Knight JL, Kaus JW, Cerutti DS, Krilov G, Jorgensen WL, Abel R, Friesner RA (2016) OPLS3: a force field providing broad coverage of drug-like small molecules and proteins. J Chem Theory Comput 12:281-296. https://doi.org/10.1021/acs.jctc.5b00864

63. Shivakumar D, Williams J, Wu Y, Damm W, Shelley J, Sherman W (2010) Prediction of absolute salvation free energies using molecular dynamics free energy perturbation and the OPLS force field. J Chem Theory Comput 6:1509-1519. https://doi.org/10.1021/ct900587b

64 Jorgensen WL, Maxwell DS, Tirado-Rives J (1996) Development and testing of the OPLS all-atom force field conformational energetic and properties of organic liquids. $\mathrm{J}$ Am Chem Soc 118:11225-11236. https://doi.org/10.1021/ja9621760 
65. Jorgensen WL, Tirado-Rives J (1988) The OPLS [optimized potentials for liquid simulations] potential for proteins, energy minimizations for crystals of cyclic peptides and crambin. J Am Chem Soc 119:1657-1666. https://doi.org/10.1021/ja00214a001

66. Berendsen HJC, Postma JPM, van Gunsteren WF, Hermans J (1981) Interaction models for water in relation to protein hydration, in: Intermol. Forces, Springer pp. 331-342.

67. Oostenbrink C, Villa A, Mark AE, Van Gunsteren WF (2004) A biomolecular force field based on the free enthalpy of hydration and solvation: the GROMOS force field parameter sets 53A5 and 53A6. J Comput Chem 25(13):1656-1676.

https://doi.org/10.1002/jcc.20090

68. Hess B, Kurzner C, van der Spoel D, Lindahl E (2008) GROMACS 4: Algorithms for highly efficient, load balanced and scalable molecular simulation. J Chem Theory Comput 4(3):435-447. https://doi.org/10.1021/ct700301q

69. Webb B, Saji A (2016) Comparative protein structure modelling using Modeller. Current Protocols in Bioinformatics 54:5.6.1-5.6.37. https://doi.org/10.1002/cpbi.3

70. Berendsen HJC, van der Spoel D, van Drunen R (1995) GROMACS: a message passing parallel molecular dynamics implementation. Computer Physics Communications 91(1-3): 43-56. https://doi.org/10.1016/0010-4655(95)00042-E

71. Lindahl E, Hess B, van der Spoel D (2001) GROMACS3.0: a package for molecular simulation and trajectory analysis. Molecular Modeling Annual 7:306-317. https://doi.org/10.1007/s008940100045

72. Humphrey W, Dalke A, Schulten K (1996) VMD: visual molecular dynamics. J Mol Graph 14(1):33-38. https://doi.org/10.1016/0263-7855(96)00018-5

73. Schrodinger L (2010) The PyMOL molecular graphics system, Version 1.3r1.

74. Turner P (2005) XMGRACE, Version 5.1.19, Center for Coastal and land-margin research, Oregon Graduate Institute of Science and Technology, Beaverton, OR.

75. Miller III BR, McGee Jr TD, Swails JM, Homeyer N, Gohlke H, Roitberg AE (2012) MMPBSA, py: an efficient program for end-state free energy calculations. J Chem Theory Comput 8(9): 3314-3321. https://doi.org/10.1021/ct300418h

76. Trott O, Olson AJ (2010) AutoDockVina: improving the speed and accuracy of docking with a new scoring function, efficient optimization and multithreading. $\mathbf{J}$ Comput Chem 31:455-461. https://doi.org/10.1002/jcc.21334

77. Haress NG, Al-Omary F, El-Emam AA, Mary YS, Panicker CY, Al-Saadi AA, War JA, Van Alsenoy C (2015) Spectroscopic investigation (FT-IR and FT-Raman), vibrational assignments, HOMO-LUMO analysis and molecular docking study of 2(adamantan-1yl)-5-(4-nitrophenyl)-1,3,4-oxadiazole. Spectrochim Acta 135:973-983. https://doi.org/10.1016/j.saa.2014.07.077

78. Das KGV, Panicker CY, Narayana B, Nayak PS, Sarojini BK, Al-Saadi AA (2015) FT-IR, molecular structure, first order hyperpolarizability, NBO analysis, HOMO and LUMO and MEP analysis of 1-(10H-phenothiazin-2-yl)ethanone by HF and densityfunctional methods. Spectrochim. Acta 135:162-171.

https://doi.org/10.1016/j.saa.2014.06.155

79. Panicker CY, Varghese HT, George A, Thomas PKV (2010) FT-IR, FT-Raman and ab initio studies of 1,3-diphenyl thiourea. Eur J Chem 1:173-178. https://doi.org/10.5155/eurjchem.1.3.173-178.42

80. Mary YS, Panicker CY, Narayana B, Samshuddin S, Sarojini BK, Van Alsenoy C (2014) FT-IR, molecular structure, HOMO-LUMO, MEP, NBO analysis and first order hyperpolarizabilityof methyl 4,4"'-difluoro-5-methoxy-1,1',3'1'-tertphenyl-4'carboxylate. Spectrochim. Acta 133:480-488.

https://doi.org/10.1016/j.saa.2014.06.031 
81. Mary YS, Panicker CY, Yamuna TS, Siddegowda MS, Yathirajan HS, Al-Saadi AA, Van Alsenoy C (2014) Theoretical investigations on the molecular structure, vibrational spectra, HOMO-LUMO and NBO analysis of 9-[3-(dimethylamino) propyl]-2-trifluoro-methyl-9H-thioxanthen-9-ol. Spectrochim. Acta 132:491-501. https://doi.org/10.1016/j.saa.2014.05.016

82. Yang W, Zhou W, Zhang Z (2007) Structural and spectroscopic study of N-2fluorobenozyl-N-4-methoxyphenylthiourea. J Mol Struct 828:46-53.

https://doi.org/10.1016/j.molstruc.2006.05.033

83. Colthup NB, Daly LH, Wiberly SE (1975) Introduction of Infrared and Raman Spectroscopy, Academic Press, New York.

84. Mary YS, Varghese HT, Panicker CY, Ertan T, Yildiz I, Temiz-Arpaci O (2008) Vibrational spectroscopic studies and ab initio calculations of 5-nitro-2-(pfluorophenyl)benzoxazole. Spectrochim Acta 71:566-571. https://doi.org/10.1016/j.saa.2007.12.041

85. Mary YS, Panicker CY, Sapnakumari M, Narayana B, Sarojini BK, Al-Saadi AA, Van Alsenoy C, War JA (2015) Molecular structure, FT-IR, vibration assignments, HOMO-LUMO, MEP, NBO analysis and molecular docking study of ethyl-6-(4chlorophenyl)-4-(4-fluorophenyl)-2-oxocyclohex-3-ene-1-carboxylate. Spectrochim Acta 138:73-84. https://doi.org/10.1016.j.saa.2014.11.012

86. Roeges NPG (1994) A Guide to the Complete Interpretation of Infrared Spectra of Organic Structures, John Wiley and Sons Inc., New York.

87. Socrates G (1981) Infrared Characteristic Group Frequencies, John Wiley and Sons, New York.

88. S. Nigam, M.M. Patel, A. Ray, Normal coordinate analysis and CNDO/II calculations of isonitrosopropiohenone (propiophenone oxime) and its semicarbazone and thiosemicarbazone derivatives, synthesis and characterization of their metal complexes, J. Phys. Chem. Solids, 61 (2000) 1389-1398.

https://doi.org/10.1016/S0022-3697(00)0025-1

89. Varsanyi G (1974) Assignments of Vibrational Spectra of Seven Hundred Benzene Derivatives, Wiley, New York.

90. Raju R, Panicker CY, Nayak PS, Narayana B, Sarojini BK, Van Alsenoy C, Al-Saadi AA (2015) FT-IR, molecular structure, first order hyperpolarizability, MEP, HOMO and LUMO analysis and NBO analysis of 4-[(3-acetylphenyl)amino]-2-methylidene-4oxobutanoic acid. Spectrochim Acta 134:63-72. https://doi.org/10.1016/j.saa.2014.06.051

91. Sebastian SHR, Al-Alshaikh MA, El-Emam AA, Panicker CY, Zitko J, Dolezal M, Van Alsenoy C (2016) Spectroscopic, quantum chemical studies, Fukui functions, in vitro antiviral activity and molecular docking of 5-chloro-N-(3-nitrophenyl)pyrazine$\begin{array}{lllll}\text { 2-carboxamide. } & \mathrm{J} & \text { Mol } & \text { Struct }\end{array}$ https://doi.org/10.1016/j.molstruc.2016.04.088

92. El-Azab AS, Jalaja K, Abdel-Aziz AAM, Al-Obaid AM, Mary YS, Panicker CY, Van Alsenoy C (2016) Spectroscopic analysis (FT-IR, FT-Raman and NMR) and molecular docking study of ethyl 2-(4-oxo-3-phenethyl-3,4-dihydroquinazolin-2ylthio)-acetate. $\quad \mathrm{J} \quad \mathrm{Mol} \quad$ Struct $\quad 1119: 451-461$. https://doi.org/10.1016/j.molstruc.2016.05.004

93. NBO Version 3.1, E. D. Glendening, A. E. Reed, J. E. Carpenter, and F. Weinhold, Pittsburgh, A, Gaussian Inc. 2003.

94. Mary YS, Panicker CY, Sapnakumari M, Narayana B, Sarojini BK, Al-Saadi AA, Van Alsenoy C, War JA, Fun HK (2015) Infrared spectrum, structural and optical properties and molecular docking study of 3-(4-fluorophenyl)-5-phenyl-4,5-dihdyro- 
1H-pyrazole-1-carbaldehyde. Spectrochim Acta 138:529-538. https://doi.org/10.1016/j.saa.2014.11.041

95. Sheeja SR, Mangalam NA, Kurup MRP, Mary YS, Raju K, Varghese HT, Panicker CY (2010) Vibrational spectroscopic studies and computational study of quinoline-2carbaldehyde benzoyl hydrazone. J Mol Struct 973:36-46. https://doi.org/10.1016/j.molstruc.2010.03.016

96. Mary YS, Panicker CY, Sapnakumari M, Narayana B, Sarojini BK, Al-Saadi AA, Van Alsenoy C, War JA, Fun HK (2015) Molecular structure, FT-IR, Vibrational assignments, HOMO-LUMO analysis and molecular docking study of 1-[5-(4Bromophenyl)-3-(4-fluorophenyl)-4,5-dihydro-1H-pyrazol-1-yl]ethanone.

Spectrochim Acta 136:473-482. https://doi.org/10.1016/j.saa.2014.09.060

97. Mary YS, Miniyar PB, Mary YS, Resmi KS, Panicker CY, Armakovic S, Armakovic SJ, Thomas R, Sureshkumar B (2018) Synthesis and spectroscopic study of three new oxadiazole derivatives with detailed computational evaluation of their reactivity and pharmaceutical potential. J Mol Struct 1173: 469-480.

https://doi.org/10.1016/j.molstruc.2018.07.076

98. Mary YS, Mary YS, Thomas R, Narayana B, Samshuddin S, Sarojini BK, Armakovic S, Armakovic SJ, Pillai GG (2019) Theoretical studies on the structure and various physic-chemical and biological properties of a terphenyl derivative with immense antiprotozoan activity. Polycyclic Aromatic Compounds

https://doi.org/10.1080/10406638.2019.1624974

99. Shafieyoon P, Mehdipour E, Mary YS (2019) Synthesis, characterization and biological investigation of glycine based sulfonamide derivative and its complex: Vibration assignment, HOMO-LUMO analysis, MEP and molecular docking. J Mol Struct 1181:244-252. https://doi.org/10.1016/j.molstruc.2018.12.067

100. Politzer P, Murray JS (2002) The fundamental nature and role of the electrostatic potential in atoms and molecules. Theor Chem Acc 108:134-142. https://doi.orgG/10.1007/s00214-002-0363-9

101. Politzer P, Laurence PR, Jayasuriya K (1985) Molecular electrostatic potentials: an effective tool for the elucidation of biochemical phenomena. Environ. Health Perspect 61:191-202. https://doi.org/10.1289/ehp.8561191

102. Politzer P, Murray JS, Bulat FA (2010) Average local ionization energy: a review. J Mol Model 16:1731-1742. https://doi.org/10.1007/s00894-010-0709-5

103. Politzer P, Abu-Awwad F, Murray JS (1998) Comparison of density functional and Hartree-Fock average local ionization energies on molecular surfaces. Int J. Quantum Chem 69: 607-613. https://doi.org/10.1002/(SICI)1097-461X(1998)69:4<607::AIDQUA18>3.0.CO;2-W

104. Andersson T, Broo A, Evertsson E (2014) Prediction of drug candidate's sensitivity toward autoxidation: computational estimation of $\mathrm{CH}$ dissociation energies of carboncentered radicals. J Pharm Sci 103:1949-1955. https://doi.org/10.1002/jps.23986

105. Raillard SP, Bercu J, Baertschi SW, Riley CM (2010) Prediction of drug degradation pathways leading to structural alerts for potential genotoxic impurities. Org Process Rev Dev 14:1015-1020. https://doi.org/10.1021/op100007q

106. Wright JS, Shadnia H, Chepelev LL (2009) Stability of carbon-centered radicals: Effect of functional groups on the energetics of addition of molecular oxygen. $\mathrm{J}$ Comput Chem 30:1016-1026. https://doi.org/10.1002/jcc.21124

107. Gryn'ova G, Hodgson JL, Coote ML (2011) Revising the mechanism of polymer autoxidation. Org Biomol Chem 9:480-490. https://doi.org/10.1039/C0OB00596G 
108. Greenhalgh DJ, Williams AC, Timmins P, York P (1999) Solubility parameters as predictors of miscibility in solid dispersions. J Pharm Sci 88:1182-1190. https://doi.org/10.1021/js9900856

109. Rowe RC (1988) Adhesion of film coatings to tablet surfaces- a theoretical approach based on solubility parameters. Int J Pharm 41:219-222. https://doi.org/10.1016/0378$\underline{5173(88) 90195-0}$

110. Rowe RC (1989) Interactions in coloured powders and tablet formulations: a theoretical approach based on solubility parameters. Int $\mathrm{J}$ Pharm 53:47-51. https://doi.org/10.1016/0378-5173(89)90360-8

111. Lagunin A, Stepanchikova A, Filimonov D, Poroikov V (2000) PASS: prediction of activity spectra for biologically active substances. Bioinformatics 16:747-748. https://doi.org/10.1093/bioinformatics/16.8.747

112. Nahata R, Hortobagyi GN, Esteva FJ (2003) Growth factor receptors in breast cancer: potential for therapeutic intervention. Oncologist 8: 5-17. https://doi.org/10.1634/theoncologist.8-15

113. Normanno N, De Luca A, Bianco C, Strizzi L, Mancino M, Maiello MR, Carotenuto A, De Feo G, Caponigro F, Salomon DS (2006) Epidermal growth factor receptor (EGFR) signalling in cancer. Gene 17:2-16. https://doi.org/10.1016/j.gene.2005.10.018

114. Alqasoumi SI, Alsaid MS, Abdel-Kader MS, Ghorab MM (2015) Semisynthsis of novel sulphonamides, thioureas and biphenylsulfones as a new class of anticancer agents by using L-Norephedrine as strategic starting material. Acta Poloniae Pharmaceutica-Drug Research 72:1183-1191.

115. Kumar V, Kumar A, Sureshbabu VV, Chimni SS (2014) Synthesis and stereochemistry-activity relationship of chiral thiourea derivatives as potential anticancer agents. Anticancer Agents Med Chem 14:910-920. https://doi.org/10.2174/18715206113136660368

116. Yang HY, Ahmad ZA, Song Y (2020) Molecular insights for the role of key residues of calreticulin in its binding activities. Comput Biol Chem 85:107228. https://doi.org/10.1016/j.compbiolchem.2020.107228

\section{Figure captions}

Fig.1 Optimized geometry of FPTT

Fig.2 HOMO-LUMO plots of FPTT

Fig.3 MEP and ALIE surfaces of FPTT molecule, expressed in $\mathrm{kcal} / \mathrm{mol}$

Fig.4 H-BDE values in case of FPTT molecule, expressed in $\mathrm{kcal} / \mathrm{mol}$

Fig.5 Selected RDFs of FPTT molecule 
Figures

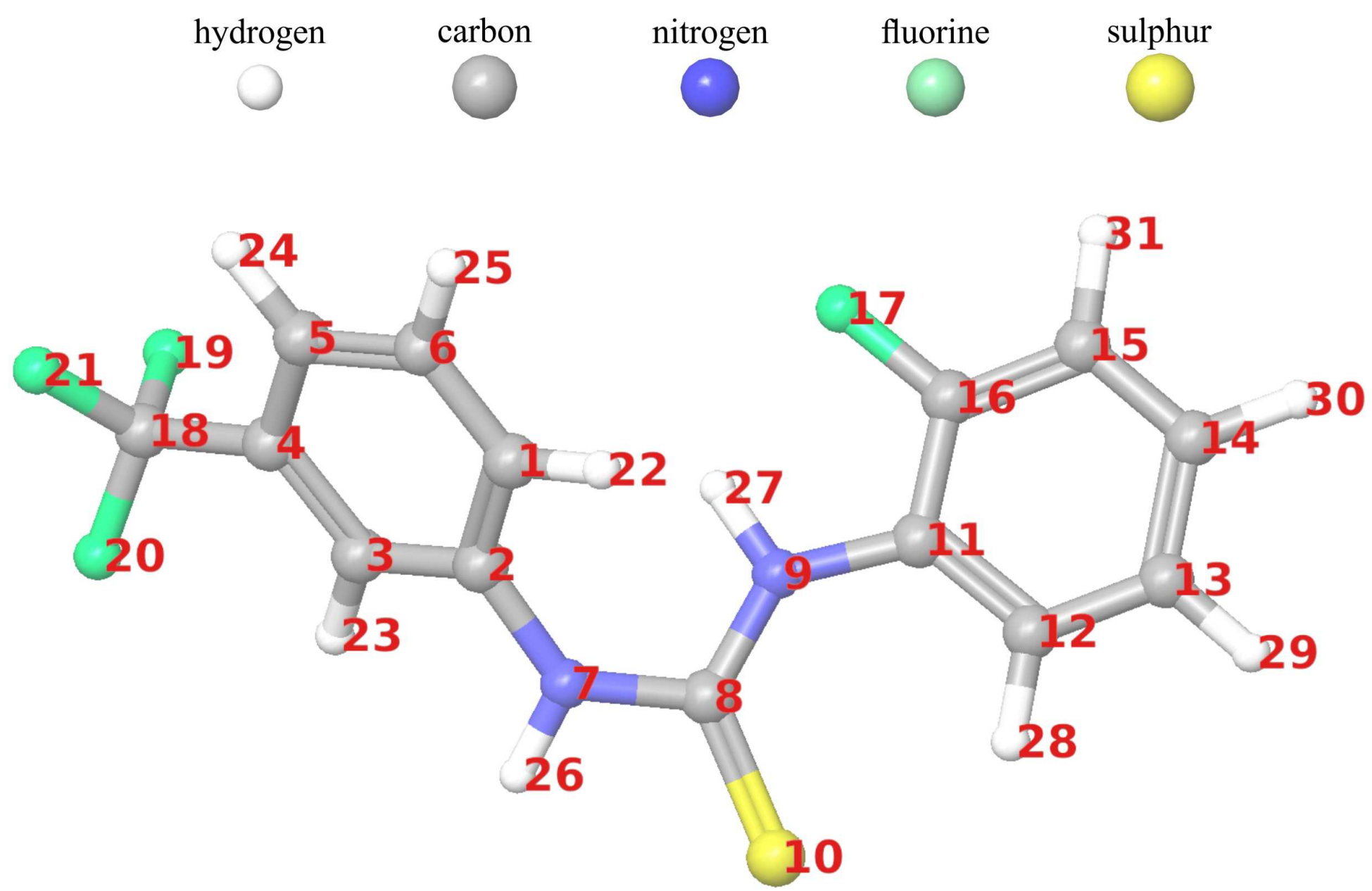

Figure 1

Optimized geometry of FPTT 

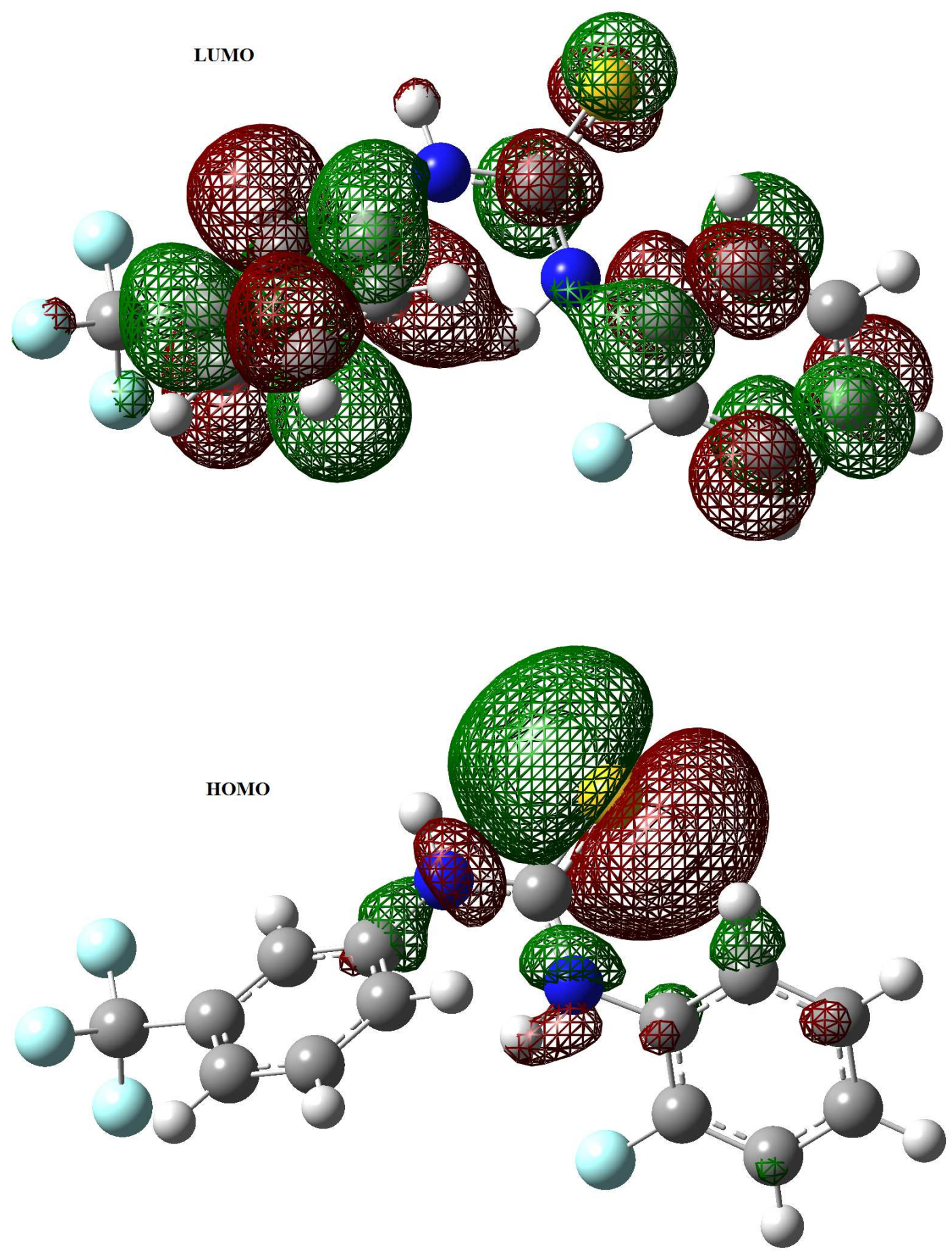

Figure 2

HOMO-LUMO plots of FPTT 


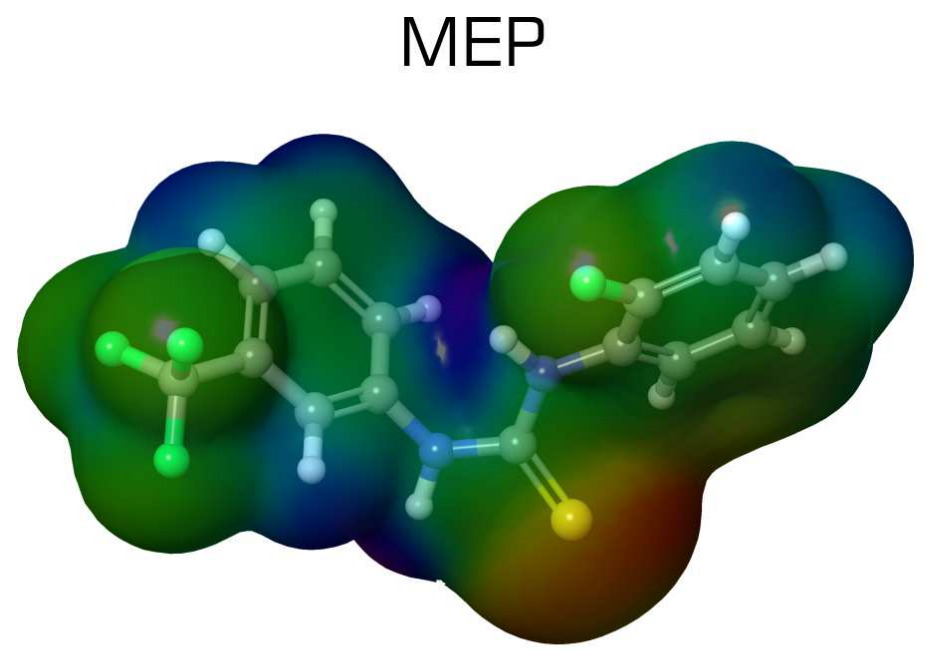

$-32.58$

40.52

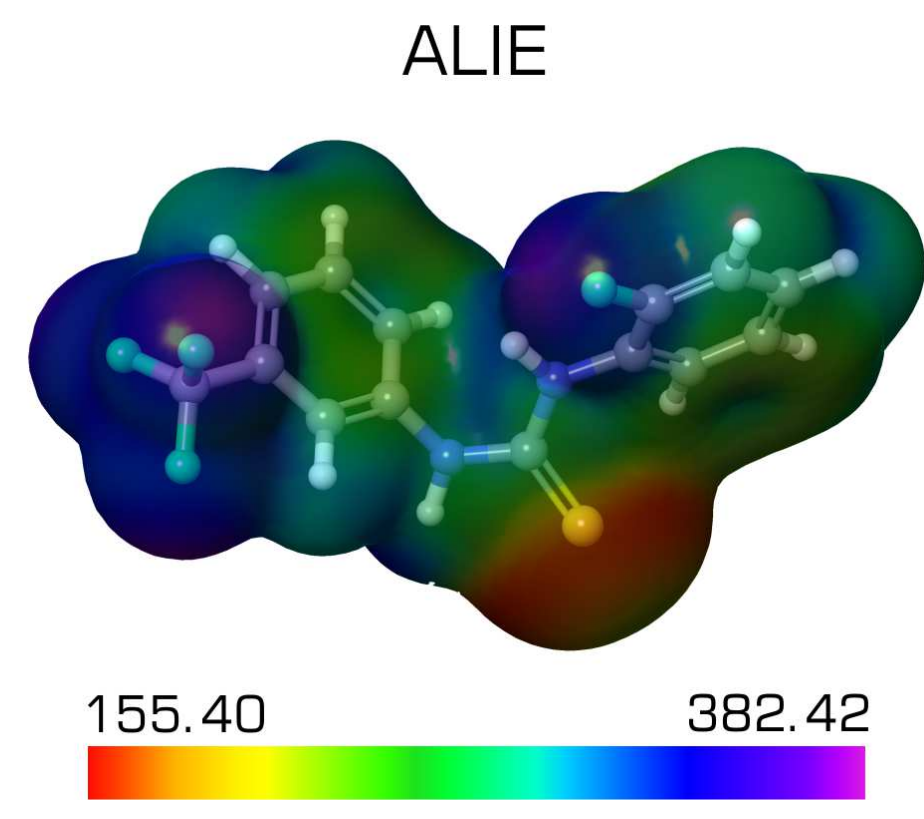

Figure 3

MEP and ALIE surfaces of FPTT molecule, expressed in $\mathrm{kcal} / \mathrm{mol}$

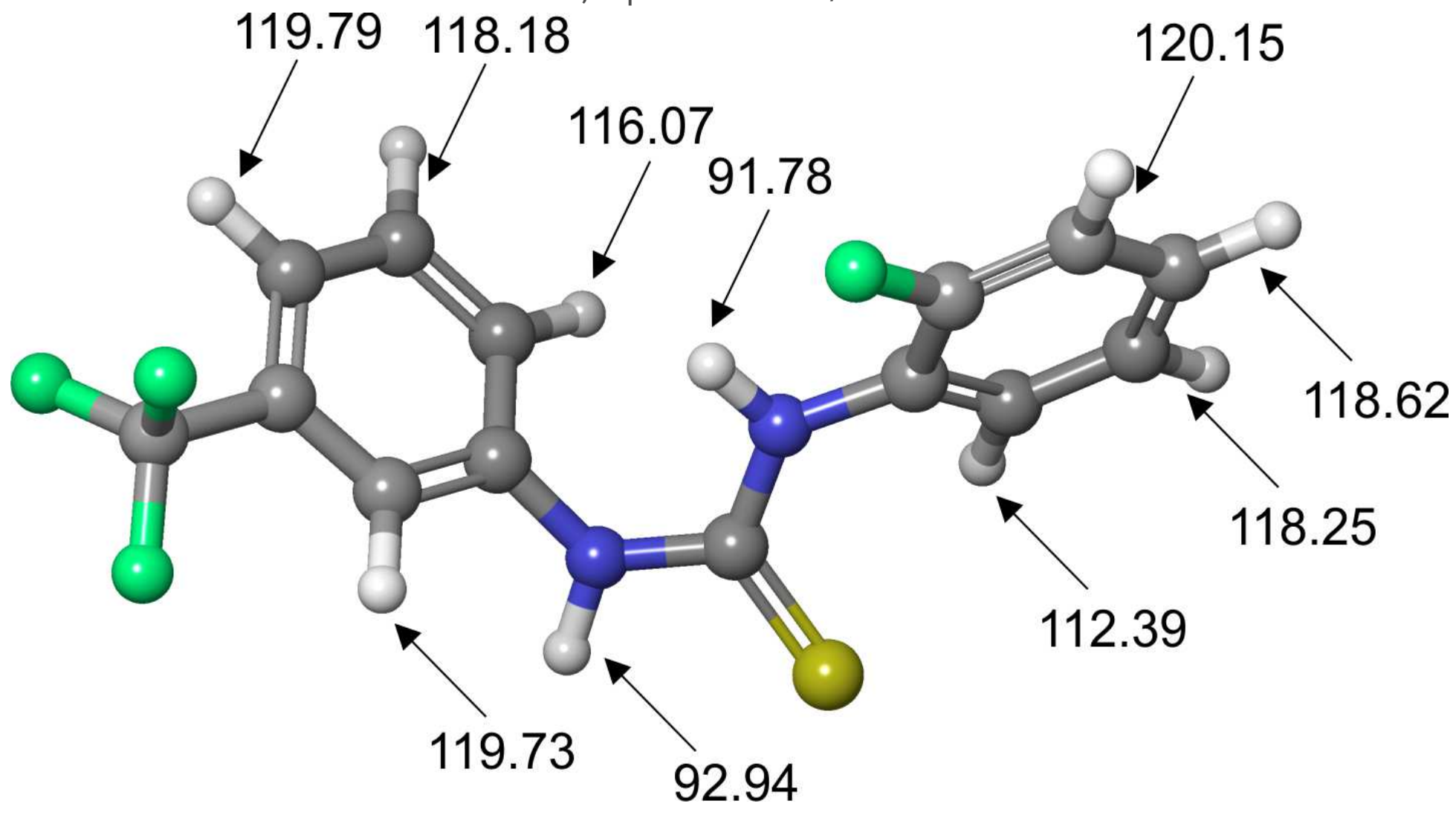

Figure 4

$\mathrm{H}-\mathrm{BDE}$ values in case of FPTT molecule, expressed in $\mathrm{kcal} / \mathrm{mol}$

\section{Supplementary Files}


This is a list of supplementary files associated with this preprint. Click to download.

- Fig.S1S5.docx

- tableS1.docx

- tables2.doc

- tableS3.docx

- tableS4.docx

- graphicalabstract.docx 